\title{
Pegvisomant therapy in pituitary gigantism: successful treatment in a 12-year-old girl
}

\author{
M Rix, P Laurberg ${ }^{1}$, A S Hoejberg and B Brock-Jacobsen ${ }^{2}$ \\ Departments of Paediatrics and ${ }^{1}$ Endocrinology and Internal Medicine, Aalborg University Hospital, 9000 Aalborg, Denmark and ${ }^{2}$ Department of \\ Paediatrics, Odense University Hospital, 5000 Odense, Denmark
}

(Correspondence should be addressed to M Rix; Email: mariane.rix@dadlnet.dk)

\begin{abstract}
Objective: The use of a growth hormone $(\mathrm{GH})$ receptor antagonist, pegvisomant has shown great promise in adults with acromegaly, but experience in paediatric patients is lacking. We aimed to describe the results of pegvisomant therapy in a 12-year-old girl with an aggressive GH-secreting pituitary tumour.

Design: To evaluate the ability of pegvisomant therapy to control the effects of peripheral GH excess in a case of pituitary gigantism.

Methods: Pegvisomant was introduced at $10 \mathrm{mg} /$ day, given subcutaneously, and gradually increased to $20 \mathrm{mg} /$ day until serum IGF-I was normal for age.

Results: A large pituitary adenoma with suprasellar extension was diagnosed in a 12-year-old girl with progressive tall stature $(178 \mathrm{~cm})$, GH hypersecretion without suppression during oral glucose loading (nadir serum GH, 90 mU/l), high serum IGF-I and serum prolactin levels. Surgical extirpation was not possible because tumour tissue was fibrous and adherent to the optical nerves. Histological examination showed a mixed GH- and prolactin-secreting adenoma with lymphocytic infiltration of B and T cells. Treatment with a dopamine agonist, cabergoline, normalized serum prolactin, but GH secretion was resistant to both somatostatin analogue, octreotide and cabergoline. Radiation followed by pegvisomant therapy titrated up in dose to $20 \mathrm{mg}$ /day led to a marked reduction in $\mathrm{GH}$ secretion and normalization of IGF-I, and to growth arrest and improvement of well-being.

Conclusions: We suggest that treatment in pituitary gigantism with pegvisomant is safe and may normalize IGF-I levels and effectively stop growing.
\end{abstract}

European Journal of Endocrinology 153 195-201

\section{Introduction}

Gigantism refers to growth hormone $(\mathrm{GH})$ excess that occurs during childhood when epiphyseal growth plates allow excessive linear growth, whereas acromegaly indicates the same phenomenon occurring in adulthood. The two disorders may partially overlap depending on the developmental stage during which such excess originates, with about $10 \%$ of acromegalics exhibiting tall stature (1). True gigantism is extremely rare, usually caused by a pituitary adenoma (2-4).

GH-secreting adenomas seem to be more invasive and aggressive in childhood than in adulthood $(4,5)$. Surgery has traditionally been the first line of treatment, with radiation reserved for cases that were not surgically curable. Medical therapy has taken on a more important role in the management of patients with GH excess with development of somatostatin analogues and dopamine agonists. Recently a novel GH receptor antagonist, pegvisomant $(6,7)$ has shown great promise in adults with acromegaly $(8,9)$, but experience in paediatric patients is lacking.

\section{Subject and methods}

Serum GH was measured by a time-resolved immunofluorometric assay specific for the $22-\mathrm{kD}$ GH protein (Delfia, Perkin Elmer Life Sciences, Turku, Finland) (10) with a detection limit of $0.05 \mathrm{mU} / \mathrm{l}$ and intraand interassay coefficients of variation of $<5 \%$ and $<6 \%$ respectively, and with no cross-reactivity with pegvisomant. The conversion factor from $\mathrm{mU} / \mathrm{l}$ to $\mu \mathrm{g} / \mathrm{l}$ with this assay is 0.38 .

An oral glucose tolerance test (OGTT) was performed with the patient in a fasting and resting state before and during the test. An oral glucose solution $(75 \mathrm{~g})$ was ingested in the first $5 \mathrm{~min}$ of the test. Blood samples for determinations of glucose and growth hormone 
levels were collected at $-30,0,30,45,60,90,120$, 150 and $180 \mathrm{~min}$.

Serum insulin-like growth factor-I (IGF-I) was determined by acid-ethanol-extracted RIA, and the national age-adjusted normal ranges of IGF-I levels were used in interpreting the results (11). The reference for IGF-I $($ mean \pm 2 S.D.) at the age of $12-13$ years is 464 $(227-785) \mathrm{ng} / \mathrm{ml}$ and at the age of $13-14$ years it is $517(264-853) \mathrm{ng} / \mathrm{ml}$.

Serum prolactin was analysed by ADVIA Centaur (Bayer). The conversion factor from $\mathrm{mU} / \mathrm{l}$ to $\mathrm{ng} / \mathrm{ml}$ is 0.047 .

Radiation therapy was prepared by a pretreatment magnetic resonance imaging (MRI) and delivered as megavoltage irradiation using three linear accelerator fields. Informed consent to participate in the study was obtained from the patient and her parents.

\section{Case report}

A 12-year-old girl was referred to our paediatric clinic because of extreme tall stature. Her height was $178 \mathrm{~cm}(+3.7$ SDS) and her weight $84.7 \mathrm{~kg}(+5.5$ SDS). Her growth velocity had accelerated from the age of 8 years (Fig. 1). Two years earlier she had undergone surgery for epiphysiolysis coxae. She presented with enlarged hands and feet, and increased thickness of the skin but only discreet facial features with prognathic mandibles. Her body proportions were normal (Fig. $2 a$ and $b$ ). She complained of headaches, excessive sweating, arthralgia and muscle pain, visual problems and sleep apnea. Pubertal development was Tanner stage $\mathrm{B} 2$ and P2. Bone age was normal for chronological age (Greulich-Pyle). There was no family history of tall stature (father, $180 \mathrm{~cm}$; mother, $175 \mathrm{~cm}$ ) or any endocrine diseases.

GH hypersecretion was diagnosed with very high levels of serum GH without suppression during OGTT (nadir serum GH, $90 \mathrm{mU} / \mathrm{l}$ ), and increased concentration of serum IGF-I $(1233 \mathrm{ng} / \mathrm{ml}$; normal range for age, $227-785 \mathrm{ng} / \mathrm{ml}$ ), and serum IGF-binding protein-3 (IGFBP-3) $(7224 \mathrm{ng} / \mathrm{ml}$; normal range for age, $3000-5500 \mathrm{ng} / \mathrm{ml})$. Serum prolactin was high (3990 mU/l; normal range, 90-630 mU/l). Borderline impaired glucose tolerance was found with fasting capillary blood glucose $6.0 \mathrm{mmol} / \mathrm{l}$ (normal $3.1-$ $5.6 \mathrm{mmol} / \mathrm{l}$ ) and a $120 \mathrm{~min}$ value of $7.8 \mathrm{mmol} / \mathrm{l}$ (normal $<7.8 \mathrm{mmol} / \mathrm{l}$ ). The thyroid hormone axis and the cortisol response to adrenocorticotrophic hormone (ACTH) $(250 \mu \mathrm{g})$ stimulation test were normal. A luteinizing hormone-releasing hormone (LHRH) test showed a prepubertal response and serum estradiol was below $0.05 \mathrm{nmol} / \mathrm{l}$. Serum sodium, potassium and calcium values were normal.

Opthalmologic examination revealed impaired vision with bitemporal field defect and optic atrophy mostly on the right eye. Magnetic resonance imaging (MRI) of the

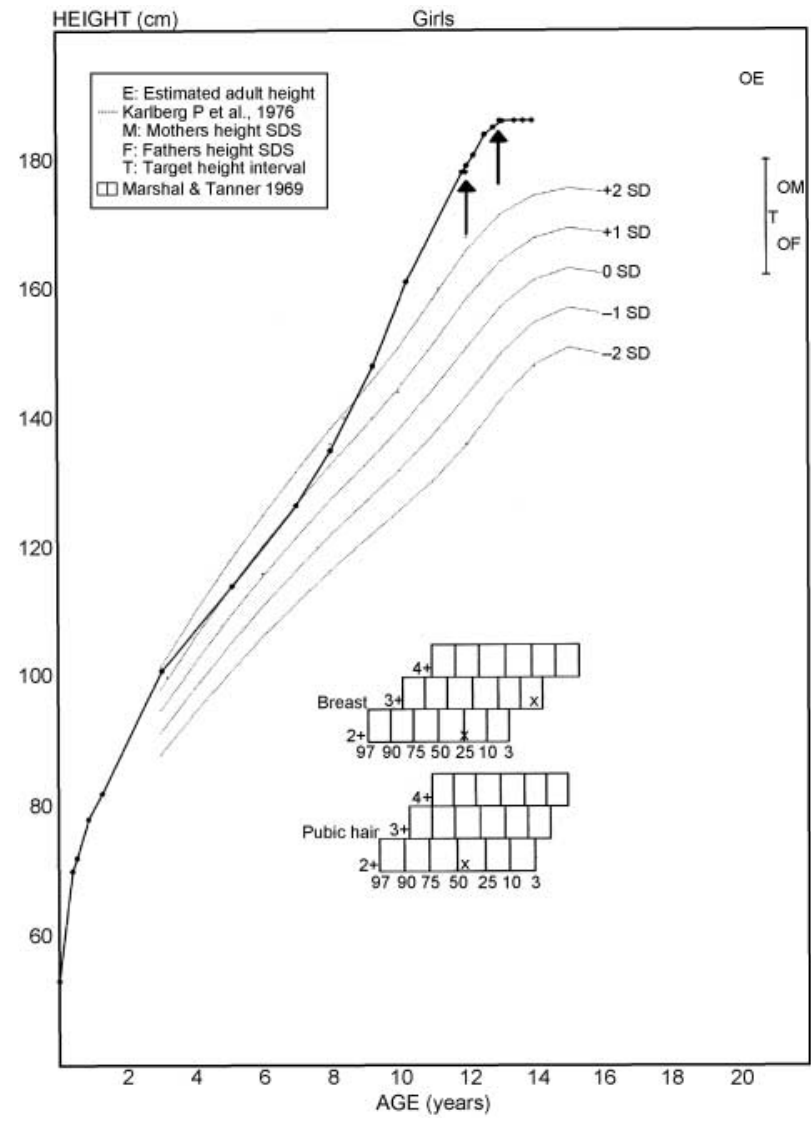

Figure 1 Growth chart illustrating the growth of the patient. The time of diagnosis and the onset of pegvisomant therapy are indicated by arrows.

brain revealed a large pituitary adenoma $(4.3 \times 3.2 \times 2.8 \mathrm{~cm})$ with suprasellar extension with impingment on the optic chiasm and invasion of the right cavernous sinus (Fig. 3a). To exclude ectopic GHRH-producing carcinoid, MRI of the abdomen and computed tomography (CT) scan of the chest were performed with normal results.

Preoperative high-dose administration of the somatostatin analogue octreotide, $100 \mu \mathrm{g}$ increasing to $200 \mu \mathrm{g}$ injected subcutaneously every $8 \mathrm{~h}$ for 3 weeks, did not reduce tumour volume. Serum IGF-I increased to $1350 \mathrm{ng} / \mathrm{ml}$, and random GH measurements in the morning $1 \mathrm{~h}$ after octreotide injections were only reduced to $89 \mathrm{mU} / \mathrm{l}$ and $86 \mathrm{mU} / \mathrm{l}$ (Fig. 4). Treatment with a dopamine agonist normalized serum prolactin. A transcranial operation to reduce tumour mass was performed, but the tumour turned out to be exceptionally fibrous and tough and adherent to the optical nerves and chiasm. Only small samples of tissue could be removed, without risk of further loss of vision. Pituitary MRI scan performed 3 months after surgery showed pituitary adenoma of unaltered size. Microscopic examination of tumour tissue showed a pituitary adenoma with an extensive mixed B- and 


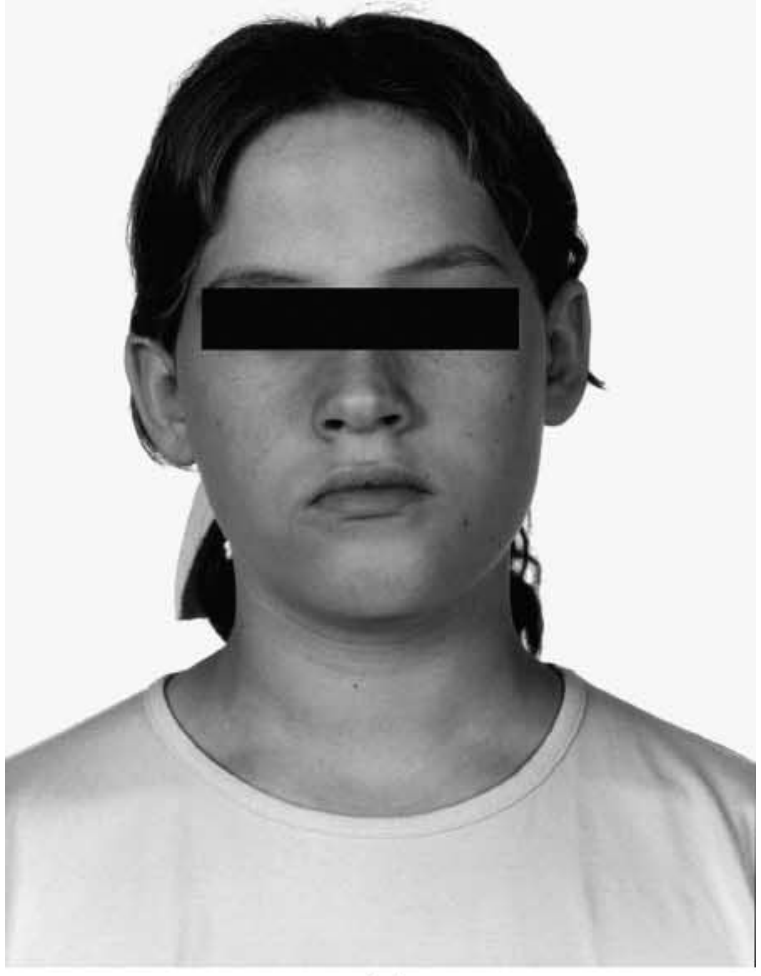

(a)

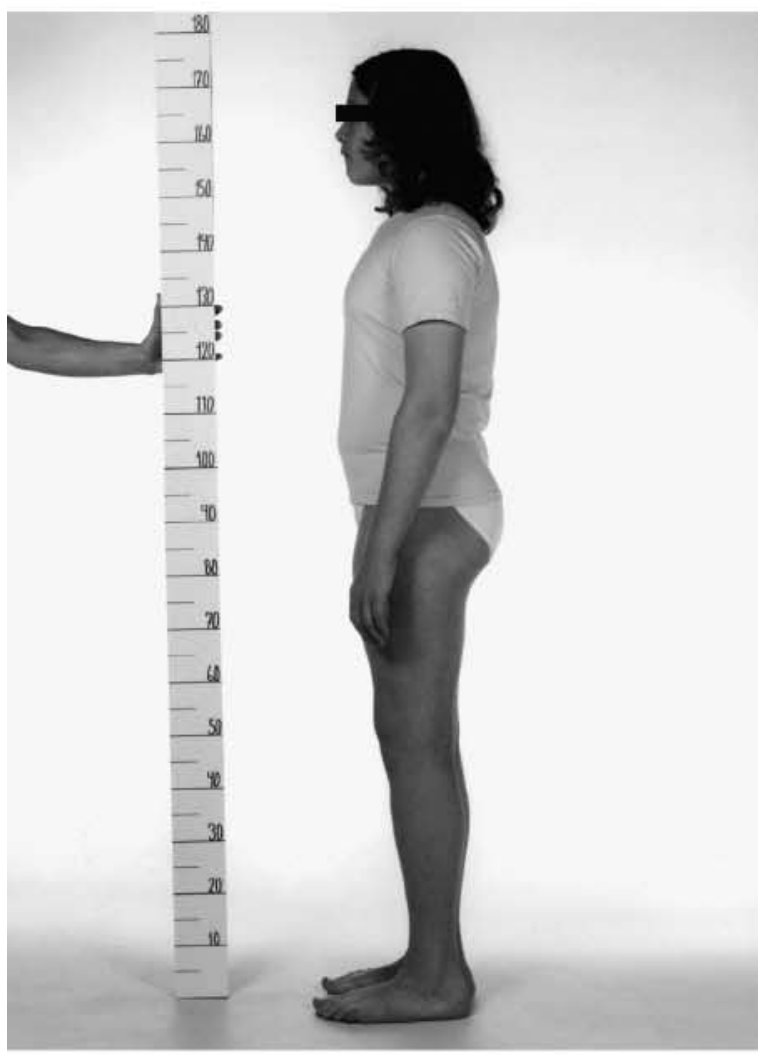

(b)

Figure 2 The patient at the time of diagnosis.

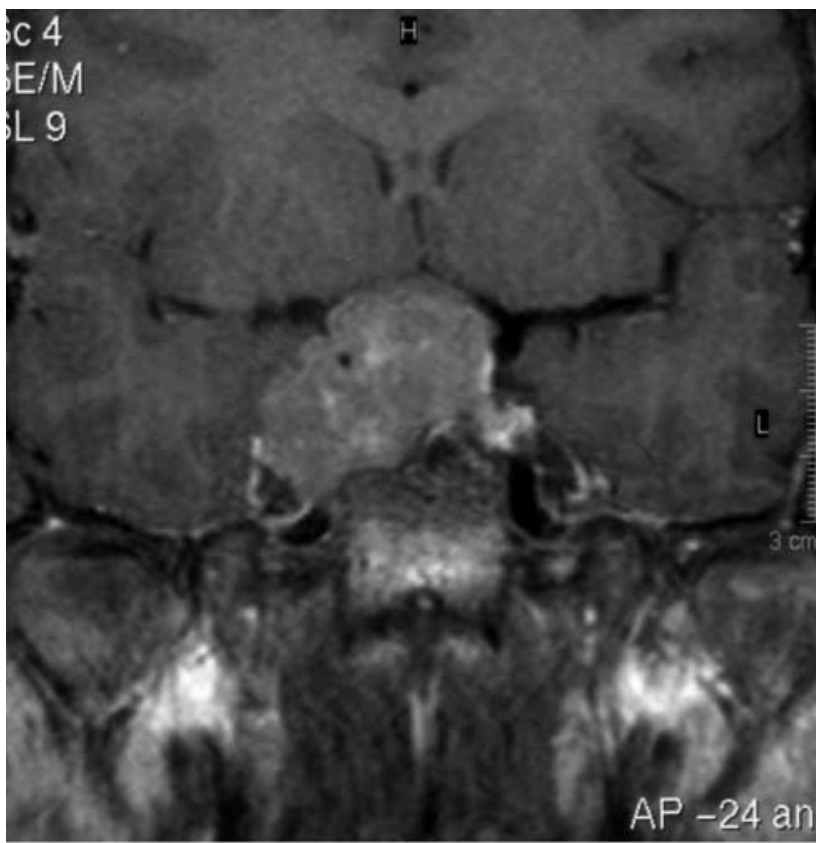

(a)

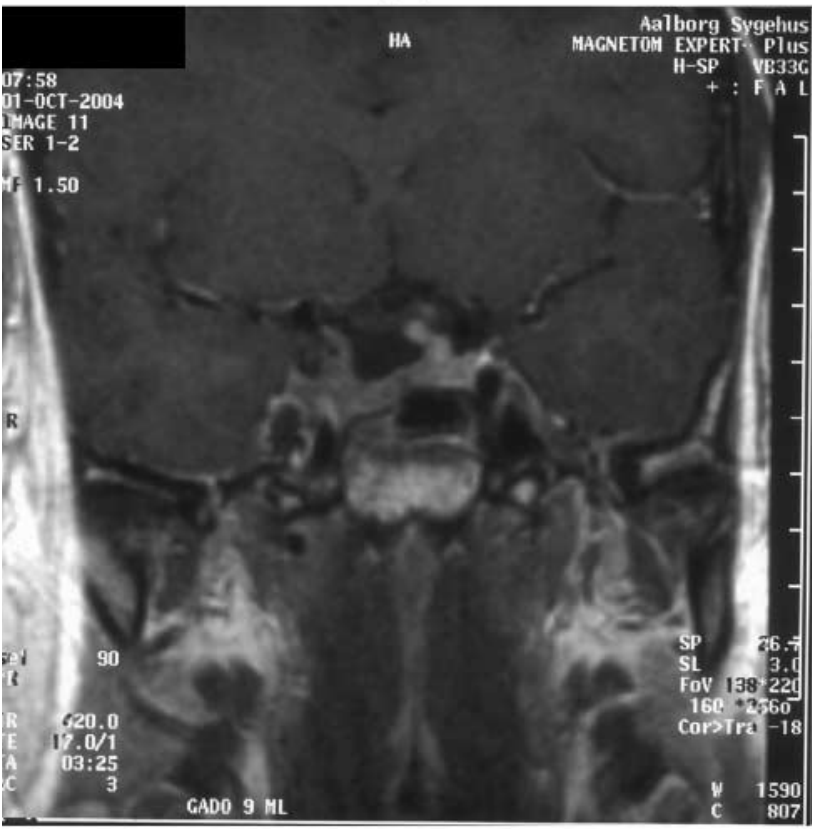

(b)

Figure $3 \mathrm{MRI}$ of the pituitary and hypothalamus before (a) and 16 months after radiotherapy (b).

T-cell inflammatory response but no signs of necrosis. The immunohistochemical staining showed adenoid cells to be positive for both $\mathrm{GH}$ and prolactin and slight reaction for $\alpha$-subunit. Lymphocytic cells were positive for $\mathrm{CD} 4, \mathrm{CD} 8$ and $\mathrm{CD} 21$ with tendency to lymphocytic aggregation with germinal centers.

Postoperatively, medical treatment with intramuscular injections of long-acting somatostatin analogue 
octreotide LAR (Sandostatin LAR, Novartis Pharma AG) at a dose of $30 \mathrm{mg}$ were given every 4 weeks for 2 months and then every 3 weeks, combined with $1 \mathrm{mg}$ cabergoline per day. However, the serum GH profiles increased further, and nadir GH during OGTT performed 3 weeks after an injection of octreotide LAR $30 \mathrm{mg}$ was $190 \mathrm{mU} / \mathrm{l}$ (Fig. 4). Therefore, octreotide LAR was discontinued after 4 months. Subsequently, irradiation of the pituitary tumour with a dose of $4500 \mathrm{cGy}$ was delivered over 25 treatment days, using five fractions per week. Three months later GH levels had fallen to $75 \mathrm{mU} / \mathrm{l}$, but IGF-I persisted at a high level $1529 \mathrm{ng} / \mathrm{ml}$ (Fig. 4). The thyroid hormone axis and the response to ACTH stimulation test were still normal. The response to LHRH test was still prepubertal, while her height had increased to $184.9 \mathrm{~cm}$ with bone age normal for chronological age.

At this time, treatment with pegvisomant was introduced at $10 \mathrm{mg} /$ day (s.c) and after 6 weeks the dose was increased to $15 \mathrm{mg}$ /day. After a few weeks of treatment, our patient already experienced a positive effect on well-being with normalization of perspiration and soft-tissue swelling, and her muscle and joint pain as well as fatigue - decreased. The daily dose was increased to $20 \mathrm{mg}$ after 4 months because IGF-I $(883 \mathrm{ng} / \mathrm{ml})$ was still over the normal range for age (Fig. 4) and she was still growing. This dose was sufficient to suppress serum IGF-I levels below the mean for age and to stop her growth, with a stagnation of height at $186 \mathrm{~cm}$ throughout the following 10 months of observation (Fig. 5). During this period bone age remained unchanged at 13.0 years.

Follow up with MRI has demonstrated a remarkable reduction of the tumour volume (Fig. $3 b$ ) and an extraordinary rapid fall in GH levels (Fig. 4). Thyroid hormone axis and ACTH $(250 \mu \mathrm{g})$ test repeated every 4-6 months have been normal. The ophthalmic status has been evaluated regularly during all phases of the disease. No alterations in visual fields or acuity have been observed.

To evaluate the current effect of pegvisomant on serum IGF-I we measured IGF-I before and after 1 week withdrawal of pegvisomant; an increase in serum IGF-I from $490 \mathrm{ng} / \mathrm{ml}$ (mean for age) to $681 \mathrm{ng} / \mathrm{ml}(+1$ s.D. for age) was observed. After reinstitution of pegvisomant, serum IGF-I fell to $350 \mathrm{ng} / \mathrm{ml}$. One month before withdrawal of pegvisomant the nadir $\mathrm{GH}$ value (range) during OGTT was $5.3(5.3-6.3) \mathrm{mU} / \mathrm{l}$ and after 1 week pause it was $6.3(6.3-7.7) \mathrm{mU} / \mathrm{l}$.

The patient has experienced no side effects of pegvisomant therapy. We have seen a normalization of glucose tolerance with fasting blood glucose $3.4 \mathrm{mmol} / \mathrm{l}$ and $120 \mathrm{~min}$ value $4.6 \mathrm{mmol} / \mathrm{l}$ during OGTT. Haemoglobin A1c (HbA1c) was 5.5\% (normal range 4.5-6.0\%) at diagnosis, this increased to $5.9 \%$ during somatostatin treatment and subsequently decreased to $5.2 \%$ during treatment with pegvisomant. Liver enzymes have been normal.

Hormonal induction of puberty has just been initiated (see Fig. 4) and the effect on growth, bone age, GH and IGF-I levels will be followed up. The patient has undergone epifyseodesis of the knees to reduce growth associated with induction of puberty.

Genetic screening for MEN1 gene mutation was negative and no clinical symptoms suggesting McCune-Albrights syndrome have been demonstrated.

\section{Discussion}

Pituitary gigantism is very rare and the description of the disease is limited to small series and case reports (12-17). In a review of reports published since 1927, Blumberg et al. (13) found only 22 cases. The median age at diagnosis was 12 years, although the median age of initial signs and symptoms was

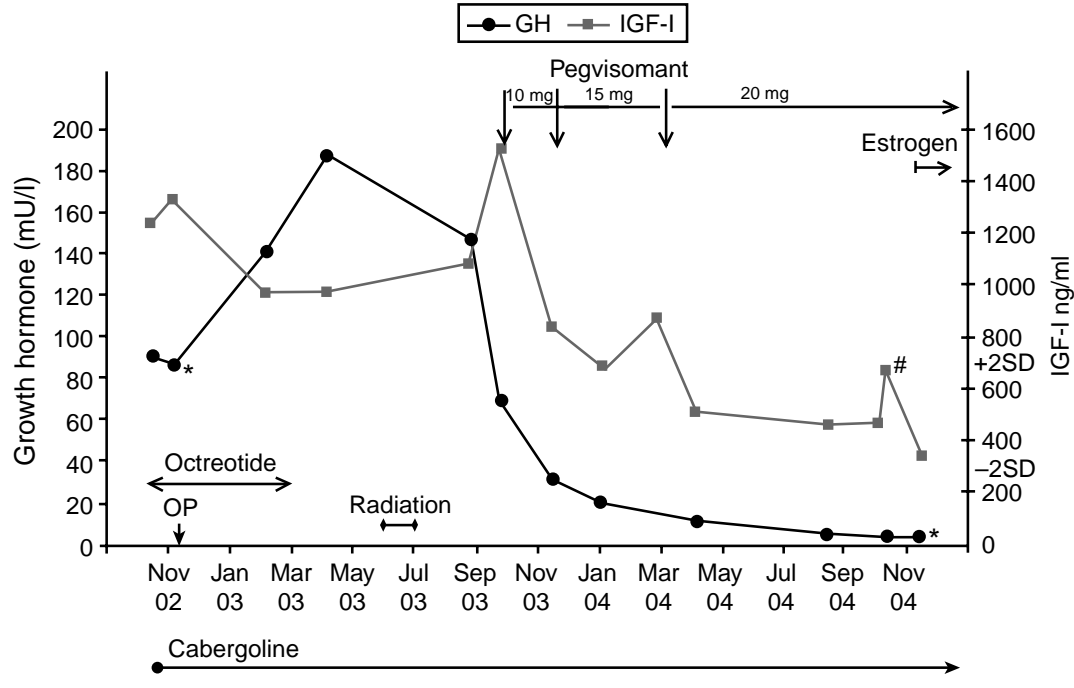

Figure 4 Serum GH and serum IGF-I concentrations at diagnosis, during pre- and postoperative treatment with cabergoline and octreotide, and radiotherapy followed by pegvisomant therapy. GH values are given as nadir GH during OGTT and in a few cases as a fasting $\left(^{*}\right)$ random $\mathrm{GH}$ measurement. The age-adjusted normal ranges for IGF-I \pm 2 S.D. are shown. \#, the result of 1-week withdrawal from pegvisomant. 


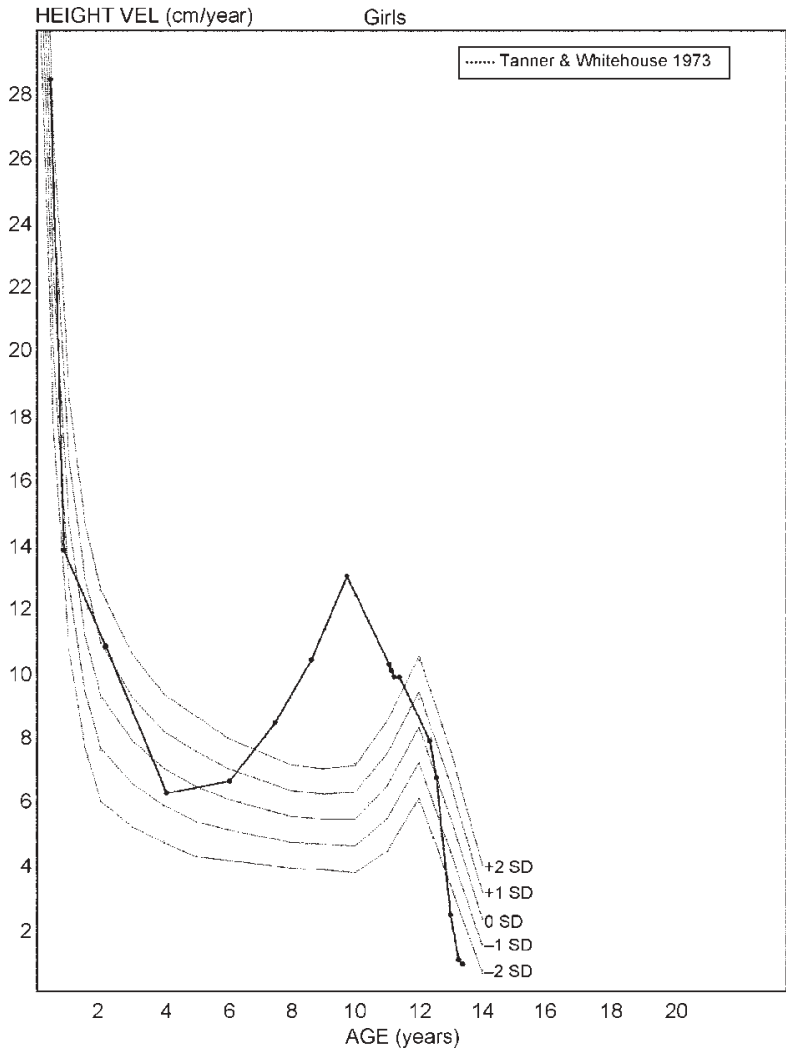

Figure 5 Growth chart illustrating the acceleration of growth velocity from the age of 8 years and the deceleration during treatment with pegvisomant.

8 years. Similarly, our patient was 12 years at diagnosis with rapid linear growth from 8 years of age. Hyperprolactinemia was noted in 12 of 15 paediatric patients, whereas in adults with a GH-secreting adenoma, its prevalence is $20-40 \%$. Even a congenital onset of $\mathrm{GH}$ excess has been suggested by linear growth acceleration occurring within the first months of life in children with documented gigantism $(12,18,19)$.

To our knowledge, the presence of extensive mixed Band T-cell inflammatory response in the tissue of a pituitary adenoma is unusual and it may suggest a component of autoimmune hypophysitis. In a case reported by McConnon et al. (20) simultaneous occurrence of a GH cell adenoma and lymphocytic infiltration of the adjacent pituitary tissue was described in a 22-year-old woman.

In pituitary adenomas transsphenoidal surgery is the recommended treatment and it may be curative $(2,4$, 5). In our patient a transcranial approach was selected because of the size and location of the tumour, but the tissue was fibrous and adherent and only small samples of tissue could be removed without risks. The somatostatin analogue, octreotide, has been found to be effective in the treatment of acromegalic patients with $\mathrm{GH}$ excess. It suppressed GH secretion and normalized IGF-I levels in over $50-70 \%$ of patients $(21-23)$, and shrank the tumour in most of patients $(22,23)$. Good results of octreotide therapy have been reported in children $(12,14-16)$. In our patient the tumour did not respond well to this treatment, and subsequently radiotherapy was performed. It is well documented that radiation may be effective in arresting growth of a GH-producing tumour, but the efficacy in decreasing $\mathrm{GH}$ secretion in acromegalic patients is delayed, with a reduction by approximately $50 \%$ by 2 years and $75 \%$ by 5 years $(24,25)$. In our patient radiation had a remarkable effect on tumour size and there was a $60 \%$ fall in $\mathrm{GH}$ levels to $75 \mathrm{mU} / \mathrm{l}$ within 3 months and to $4.5 \mathrm{mU} / \mathrm{l}$ by 18 months, but still with no pulsatility and no suppression during OGTT. Although the risk of future deterioration of the visual capacity in adults after radiotherapy has been reported to be low (26), regular ophthalmologic examination will be performed as will regular tests of pituitary function.

Recently, treatment of acromegaly with a new GHreceptor antagonist pegvisomant has been introduced. Pegvisomant is a GH analogue that binds to GH receptors on the cell surface, and blocks GH-receptor dimerisation. Thereby it inhibits GH activation of the cell, including IGF-I production $(6,7)$. The target of pegvisomant therapy is peripheral GH effects, and the efficacy of treatment is independent of tumour characteristics, such as the density and subtype of somatostatin and dopamine receptors. Because pegvisomant does not inhibit GH secretion, serum IGF-I is the best marker of efficacy of this treatment. Pegvisomant has been shown to reduce serum IGF-I concentrations effectively in both short- and long-term studies $(8,9)$, with normalization of serum IGF-I concentration in $97 \%$ of acromegalic patients treated for 12 months or more (9). Pegvisomant has been effective in acromegalic patients resistant to somatostatin analogue (27). In our patient a daily dose of $20 \mathrm{mg}$ subcutaneously was necessary to effectively stop growing by a suppression of serum IGF-I levels into the lower normal range. It is notable that under normal conditions healthy children with IGF-I levels within the lower normal range do have a growth velocity within the normal ranges for age. In the case described, the bone age remained unchanged in the same period, which may be due to a delayed pubertal development, although treatment with pegvisomant in acromegalic patients has been shown to be associated with a decrease in bone turnover correlated to the decrease in serum IGF-I (28). In acromegalic patients it has been suggested that serum IGF-I levels should not be reduced to below the upper half of the normal range in order to prevent a potential risk of functional GH deficiency (29).

The decrease in GH level and adenoma size observed during pegvisomant therapy of the patient must be caused by the radiation therapy. The extraordinary fall in $\mathrm{GH}$ levels was more rapid than normally observed after radiation therapy of GH-producing adenoma in adults $(24,25)$. Rapid cell turnover and the 
marked lymphocytic response in the large adenoma of our patient may have led to high radiation sensitivity and the very quick reduction of adenoma mass after radiotherapy. Thus, the role of pegvisomant was to accelerate the fall in peripheral $\mathrm{GH}$ effects to induce nearly immediate growth arrest. The 1-week withdrawal of pegvisomant therapy confirmed that pegvisomant did not interfere substantially with GH measurements. The half-life of pegvisomant after subcutaneous administration has been demonstrated to be up to $100 \mathrm{~h}$ (29). In a study by Jehle et al. (29) pegvisomant was withdrawn for $2-4$ weeks in three patients, who had received radiotherapy, with a rise in IGF-I above the age-adjusted normal range.

In adults long-term pegvisomant therapy has been shown to improve metabolic parameters of acromegaly such as insulin sensitivity $(9,30)$. In our patient we noticed a normalization of a slight degree of glucose intolerance at time of diagnosis. Pegvisomant appears to be safe and well tolerated in adult patients with significant improvement in well-being (7-9). Similarly our patient experienced a positive effect on well-being with normalization of perspiration and soft-tissue swelling after only a few weeks of treatment; her pain from muscles and joints decreased, as did her fatigue. No side effects were mentioned.

Recently hormonal induction of puberty has been initiated in combination with $20 \mathrm{mg}$ /day pegvisomant with close follow up of growth and bone age, as well as GH and IGF-I levels, to ensure the timing of gradual withdrawal of pegvisomant therapy as a result of the successful radiotherapy.

In conclusion pegvisomant therapy appears to be effective in normalizing serum IGF-I concentration and inducing a rapid growth arrest in pituitary gigantism and, in addition, it is safe and well tolerated.

\section{References}

1 Eugster EA \& Pescovitz OH. Commentary: gigantism. Journal of Clinical Endocrinology and Metabolism $1999 \mathbf{8 4} 4379-4384$.

2 Kane LA, Leinung MC, Scheithauer BW, Bergstrahl EJ, Laws ER Jr, Groover RV, Kovacs K, Horvath E \& Zimmerman D. Pituitary adenomas in childhood and adolescence. Journal of Clinical Endocrinology and Metabolism 199479 1135-1140.

3 Artese R, D'Osvoldo DH, Molocznik I, Benencia H, Oviedo J, Burdman JA \& Basso A. Pituitary tumors in adolescents patients. Neurological Research 199820 415-417.

4 Abe T, Tara LA \& Ludecke DK. Growth hormone-secreting pituitary adenomas in childhood and adolescence: features and results of transnasal surgery. Neurosurgery 199945 1-10.

5 Dyer EH, Civit T, Visot A, Delalande O \& Derome P. Transsphenoidal surgery for pituitary adenomas in children. Neurosurgery $199434207-212$

6 Kopchick JJ. Discovery and mechanism of action of pegvisomant. European Journal of Endocrinology 2003148 S21-S25.

7 Stewart PM. Pegvisomant: an advance in clinical efficiacy in acromegaly. European Journal of Endocrinology 2003148 S27-S32.

8 Trainer PJ, Drake WM, Katznelson L, Freda PU, Herman-Bonert V, Van der Lely AJ, Dimaraki EV, Stewart PM, Friend KE, Vance ML, Besser M \& Scarlett JA. Treatment of acromegaly with growth hormone-receptor antagonist pegvisomant. New England Journal of Medicine 2000342 1171-1177.

9 Van der Lely AJ, Hutson RK, Trainer P, Besser GM, Barkan AL, Katznelson L, Klibanski A, Herman-Bonert V, Melmed S, Lee Vance M, Freda PU, Stewart PM, Friend KE, Clemmons DR, Johansson G, Stavrou S, Cook DM, Phillips LS, Strasburger CJ, Hacker S, Zib KA, Davis RJ, Scarlett JA \& Thorner MO. Longterm treatment of acromegaly with pegvisomant, a growth hormone receptor antagonist. Lancet 2001358 1754-1759.

10 Chaler E, Belgorosky A, Marceiras M, Medioroz M \& Rivarola MA. Between-assay differences in serum growth hormone (GH) measurements: importance in the diagnosis of GH deficiency in childhood. Clinical Chemistry 200147 1735-1738.

11 Juul A, Bang P, Hertel NT, Main K, Dalgaard P, Jørgensen K, Müller J, Hall K \& Skakkebaek NE. Serum insulin-like growth factor-1 in 1030 healthy children, adolescents, and adults: relation to age, sex, stage of puberty, testicular size, and body mass index. Journal of Clinical Endocrinology and Metabolism $199478744-752$.

12 Gelber SJ, Heffez DS \& Donohoue PA. Pituitary gigantism caused by growth hormone excess from infancy. Journal of Pediatrics $1992120931-934$.

13 Blumberg DL, Sklar CA, David R, Rothenberg S \& Bell J. Acromegaly in an infant. Pediatrics 198983 998-1002.

14 Schoof E, Dorr HG, Kiess W, Ludecke DK, Freitag E, Zindal V, Rascher W \& Dotsch J. Five-year follow-up of a 13-year-old boy with pituitary adenoma causing gigantism - effect of octreotide therapy. Hormone Research 200461 184-189.

15 Minagawa M, Yasuda T, Someya T, Kohno Y, Saeki N \& Hashimoto Y. Effects of octreotide infusion, surgery and estrogen on suppression of height increase and $20 \mathrm{~K}$ growth hormone ratio in a girl with gigantism due to a growth hormone-secreting macroadenoma. Hormone Research 200053 157-160.

16 Nanto-Salonen K, Koskinen P, Sonninen P \& Toppari J. Suppression of GH secretion in pituitary gigantism by continuous subcutaneous octreotide in a pubertal boy. Acta Paediatrica $1999 \mathbf{8 8}$ $29-33$.

17 Ritzén EM, Wettrell G, Davies G \& Grant DB. Management of pituitary gigantism. The role of bromocriptine and radiotherapy. Acta Padiatrica Scandinavica 198574 807-814.

18 Zimmerman D, Young WF, Ebersold MJ, Scheithauer BW, Kovacs K, Horvath E, Whitaker MD, Eberhardt NL, Downs TR \& Frohman LA. Congenital gigantism due to growth hormonereleasing hormone excess and pituitary hyperplasia with adenomatous transformation. Journal of Clinical Endocrinology and Metabolism 199376 216-222.

19 Moran A, Sylvia L, Kovacs K, Horvath E, Singer W, Sagman U, Reubi JC, Wilson CB, Larson R \& Pescovitz OH. Gigantism due to pituitary mammosomatotroph hyperplasia. New England Journal of Medicine 1990323 322-326.

20 McConnon JK, Smyth HS \& Horvath E. A case of sparsely granulated growth hormone cell adenoma associated with lymphycytic hypophysitis. Journal of Endocrinological Investigation $1991 \mathbf{1 4}$ 691-696.

21 Ayuk J, Stewert PM, Sheppard MC \& European Sandostatin LAR Group. Efficacy of Sandostatin LAR (long-acting somatostatin analogue) is similar in patient with untreated acromegaly and in those previously treated with surgery and/or radiotherapy. Clinical Endocrinology $200460375-381$.

22 McKeage K, Cheer S \& Wagstaff AJ. Octreoitide long-acting release (LAR): a review of its use in the management of acromegaly. Drugs 200362 2473-2499.

23 Bevan JS, Atkin SL, Atkinson AB, Bouloux PM, Hanna F, Harris PE, James RA, McConnell M, Roberts GA, Scanlon MF, Stewert PM, Teasdale E, Turner HE, Wass JA \& Wardlaw JM. Primary medical therapy for acromegaly: an open, prospective, multicenter study of the effects of subcutaneous and intramuscular, slow-release octreotide on growth hormone, insuline-like growth factor-1, and tumor size. Journal of Clinical Endocrinology and Metabolism 200287 4554-4563. 
24 Eastman RC, Gordon P, Glatstein E \& Roth J. Radiation therapy of acromegaly. Endocrinology and Metabolism Clinics of North America $199221693-712$.

25 Barrande G, Pittino-Lungo M, Coste J, Ponvert D, Bertagna X, Luton JP \& Bertherat J. Hormonal and metabolic effects of radiotherapy in acromegaly: long-term results in 128 patients followed in a single center. Journal of Clinical Endocrinology and Metabolism $2000853779-3785$.

26 van den Bergh AC, Schoorl MA, Dullaart RP, van der Vliet AM, Szabo BG, ter Weeme CA \& Pott JW. Lack of radiation optic neuropathy in 72 patients treated for pituitary adenoma. Journal of Neuroophthalmology 200424 200-205.

27 Herman-Bonert VS, Zib K, Scarlett JA \& Melmed S. Growth hormone receptor antagonist therapy in acromegalic patients resistant to somatostatin analogs. Journal of Clinical Endocrinology and Metabolism 200085 2958-2961.

28 Parkinson C, Kassem M, Heickendorff L, Flyvbjerg A \& Trainer PJ. Pegvisomant-induced serum insulin-like growth factor-1 normalization in patients with acromegaly returns elevated markers of bone turnover to normal. Journal of Clinical Endocrinology and Metabolism $2003 \mathbf{8 8} 5650-5655$.

29 Jehle S, Reyes CM, Sundeen RE \& Freda PU. Alternate-day administration of pegvisomant maintains normal serum insulin-like growth factor-1 levels in patients with acromegaly. Journal of Clinical Endocrinology and Metabolism $2005901588-1593$.

30 Drake WM, Rowles SV, Roberts ME, Fode FK, Besser GM, Monson JP \& Trainer PJ. Insulin sensitivity and glucose tolerance improve in patients with acromegaly converted from depot octreoide to pegvisomant. European Journal of Endocrinology $2003149521-527$.

Received 28 February 2005

Accepted 3 May 2005 